\title{
Comparative Study of Free Fatty Acid Composition and Physico Chemical Properties of Biodiesel Produced from Various Non Edible Oil Seeds
}

\author{
Prof. S. K. Pawar \\ Associate Professor, Mechanical Engineering Department \\ Rajgad Dnyanpeeth Technical Campus, Bhor, Pune, Maharashtra, India
}

\begin{abstract}
Due to recent petroleum crisis and unavailability of petroleum diesel the demand for petroleum diesel is increasing day by day hence there is a need to find out an appropriate solution. Bio fuels are being given serious consideration as potential sources of energy in the future. Biodiesel is a clean burning alternate fuel, produced from both edible and non-edible oil seeds. It can be used in compression-ignition engines with little or no modifications. Biodiesel is simple to use, biodegradable, nontoxic, and essentially free of sulfur and aromatics. It can be stored just like petroleum diesel fuel. The use of biodiesel in conventional diesel engines results in substantial reduction of unburnt hydrocarbons, carbon monoxide and particulate matters. Its higher cetane number improves the ignition quality even when blended in petroleum diesel. Various nonedible plants in their seeds contain 30\% or more oil. Studies have been undertaken to compare free fatty acid composition and physico chemical properties of biodiesel produced from various nonedible oil seeds such as jatropha, karanja, mahua, rubber, castor, neem etc.
\end{abstract}

Keywords: Non-edible oil seeds, Diesel, Biodiesel

\section{Introduction}

The energy demand of Indian industry is increasing due to growing economic activities. Therefore India is focusing on development of renewable fuels. Biodiesel, an alternative renewable fuel made from transesterification of vegetable oil with alcohol $\&$ is becoming more readily available for use in blends with conventional diesel fuel for transportation applications. A national mission on biodiesel has been proposed in India \& specifications for diesel have been amended, to allow upto $10 \%$ blending of biodiesel in diesel. Biodiesel can be produced from edible as well as non-edible vegetable oil seeds. However India is not self sufficient in edible oils. Non-edible tree borne oilseeds (TBOs) are considered as the source of straight vegetable oil (SVO) and biodiesel. Plant species, which have $30 \%$ or more fixed oil in their seeds or kernel, have been identified. In order to explore additional oil resources, studies have been undertaken for screening of various tree borne oil seeds for their potential as biodiesel feed stock such as, Jatropha, Karanja, Castor, Mahua, Neem, Rubber etc.[1]

\section{Oil Extraction Process}

The seed kernels are to be ground, using mechanical grinder, and defatted in soxhlet apparatus. The extracted oil was obtained by filtering the solvent oil. The extracted oil is to be stored in freezer for subsequent physico chemical properties.[1] The seed oil is to be analyzed for oil content, acid value, Iodine value, Saponification value, Calorific value, kinematic viscosity, flash point, cloud point, fire point, density, cetane number etc. The disadvantages of vegetable oils as diesel fuel are;
This causes several problems during their long duration use in CI engines such as Injector coking and carbon deposits.

There are many ways and procedures to convert vegetable oil into a Diesel like fuel.
a. Pyrolisis
b. Micro emulsification
c. Dilution
d. Transesterification

\section{Transesterification Process}

The transesterification process was found to be the most viable process. Transesterified oils have proven to be a viable alternative diesel engine fuel with characteristics similar to those of Diesel fuel. Its physical and chemical properties required for operation of diesel engine are similar to petroleum based diesel fuel. Like petroleum diesel, biodiesel operates in compression-ignition engines. Transesterification is a chemical reaction that aims at substituting the glycerol of the glycerides with three molecules of monoalcohols such as Methanol thus leading to three molecules of methyl ester of vegetable oil. Methanol and ethanol is widely used in the transesterification. Methanol is used because of low cost, and physicochemical advantages with triglycerides and sodium hydroxide. The acid catalyst is the choice for transesterification when Low - grade vegetable oil used as raw material because it contains high free fatty acid (FFA) and moisture. Acid catalyst as sulphuric acid $\left(\mathrm{H}_{2} \mathrm{SO}_{4}\right)$ is used for esterification process.[2]

- High viscosity

- Low volatility

- High density 


\section{Various Nonedible Oil Seeds}

1)Jatropha (Ratan Jyot) Oil Seeds:[10]

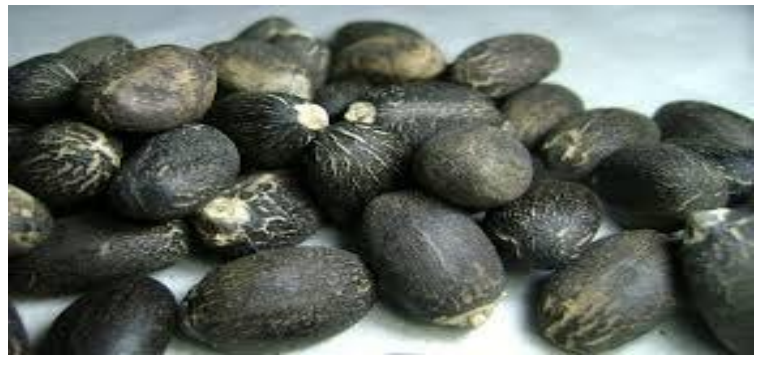

Free fatty acid composition in percentage

Linoleic: 27.25

Oleic: 47.1

Stearic: 8.22

Palmitic: 15.24

Myristic: $1.4-3$

Physico chemical properties of jatropha seed oil:

Calorific value $(\mathrm{MJ} / \mathrm{Kg})$ : 40

Kinematic viscosity $\mathrm{mm} 2 / \mathrm{s}\left(40^{\circ} \mathrm{C}\right): 8.72$

Flash point $\left({ }^{0} \mathrm{C}\right): 125$

Acid Value (mg KOH): 10.47

Pour point $\left({ }^{0} \mathrm{C}\right):-12$

Fire point $\left({ }^{0} \mathrm{C}\right): 271$

Density $\left(\mathrm{Kg} / \mathrm{m}^{3}\right): 912$

Cetane number: 57

Physico chemical properties of jatropha Biodiesel:

Calorific value $(\mathrm{MJ} / \mathrm{Kg})$ : 40

Kinematic viscosity $\mathrm{mm} 2 / \mathrm{s}\left(40^{\circ} \mathrm{C}\right): 4.328$

Flash point $\left({ }^{0} \mathrm{C}\right): 140$

Acid Value (mg KOH): 0.32

Fire point $\left({ }^{0} \mathrm{C}\right): 155$

Density $\left(\mathrm{Kg} / \mathrm{m}^{3}\right): 880$

Cetane number: 57

\section{2) Karanja (Pongamia Pinnata) oil seeds:[7][8]}

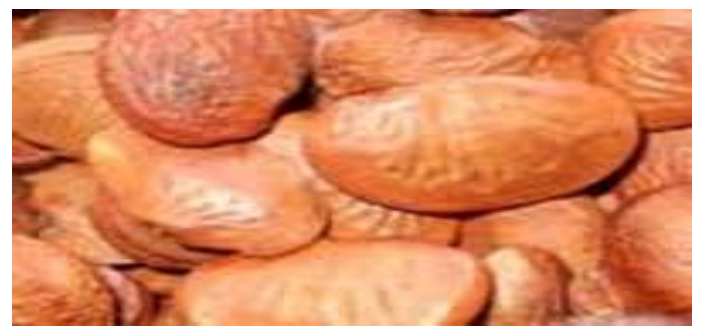

Free fatty acid composition in Percentage

Linoleic: 16.64

Linolenic: 11.65

Oleic: 51.59

Stearic: 7.5

Palmitic: 7.9

Lignoceric: $3.5-4.5$
Physico chemical properties of Karanja seed oil:

Calorific value (MJ/Kg): 36.60

Kinematic viscosity mm2/s (400C): 40.2

Flash point (0C): 225

Cloud point (0C): 3.5

Pour point (0C): -4

Density (Kg/m3): 927

Saponification Value: 184

Acid Value (mg KOH): 5.40

Physico chemical properties of Karanja Biodiesel:

Calorific value $(\mathrm{MJ} / \mathrm{Kg}): 37$

Kinematic viscosity mm2/s (400 c): 4.78

Flash point (0C): 144

Cloud point (0C): 6

Density $(\mathrm{Kg} / \mathrm{m} 3): 860$

Cetane number: 41.7

Saponification Value: 187

Acid Value (mg KOH): 0.42

2)Mahua (Madhuca Indica) oil seeds:[2][3]

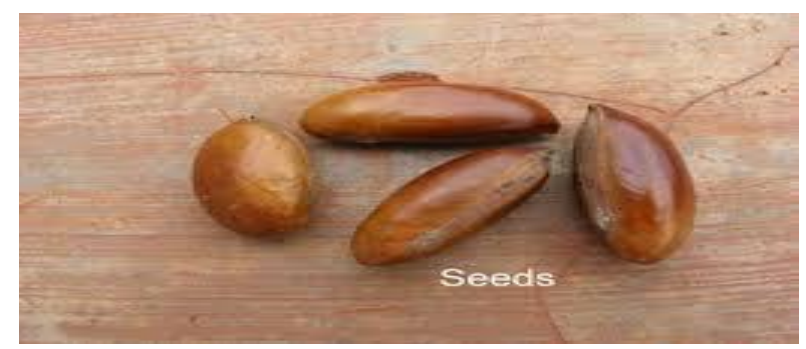

Free fatty acid composition in percentage

Linoleic: $8.9-13.7$

Palmitic: 16-28.2

Oleic: $41-51$

Stearic: $20-25.1$

Arachidic: 0-3.3

Physico chemical properties of mahua seed oil:

Calorific value $(\mathrm{MJ} / \mathrm{Kg}): 36$

Kinematic viscosity mm $2 / \mathrm{s}$ (400 c): 24.58

Flash point $\left({ }^{0} \mathrm{C}\right): 232$

Acid Value (mg KOH): 38

Fire point $\left({ }^{0} \mathrm{C}\right): 228$

Density (Kg/m3): 955

Physico chemical properties of mahua Biodiesel:

Calorific value $(\mathrm{MJ} / \mathrm{Kg}): 39$

Kinematic viscosity $\mathrm{mm} 2 / \mathrm{s}\left(40^{0} \mathrm{c}\right): 3.9$

Flash point $\left({ }^{0} \mathrm{C}\right): 205$

Acid Value (mg KOH): 0.5

Pour point $\left({ }^{0} \mathrm{C}\right): 15$

Fire point $\left({ }^{0} \mathrm{C}\right): 218$

Density $(\mathrm{Kg} / \mathrm{m} 3): 872$

Cetane number: 52 


\section{International Journal of Science and Research (IJSR) \\ ISSN (Online): 2319-7064 \\ Index Copernicus Value (2013): 6.14 | Impact Factor (2014): 5.611}

4) Rubber (Hevea Brasiliensis) oil seeds: [9]

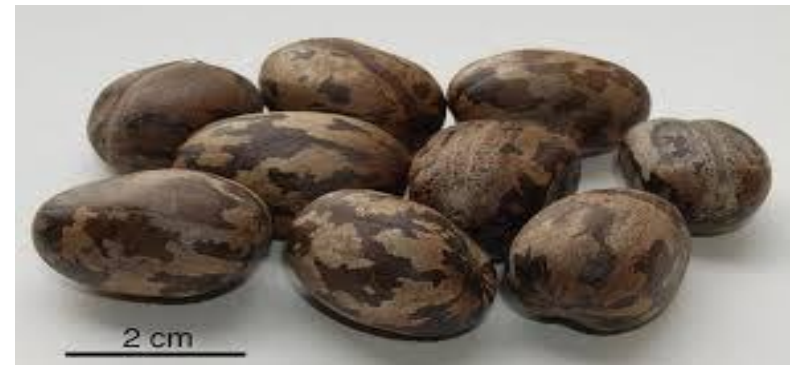

Free fatty acid composition in percentage

Linolenic: 16.3

Linoleic: 39.6

Oleic: 24.6

Stearic: 8.7

Palmitic: 10.2

Physico chemical properties of Rubber seed oil:

Calorific value $(\mathrm{MJ} / \mathrm{Kg}): 37.5$

Kinematic viscosity mm2/s (400 C): 66.2

Flash point (0C): 198

Acid Value (mg KOH): 34

Fire point (0C): 210

Density $(\mathrm{Kg} / \mathrm{m} 3): 910$

Physico chemical properties of Rubber Biodiesel:

Calorific value (MJ/Kg): 36.5

Kinematic viscosity mm2/s (400 c): 5.81

Flash point (0C): 130

Acid Value (mg KOH): 0.12

Fire point (0C): 145

Density (Kg/m3): 874

Cetane number: 54

\section{5) Castor (Ricinus Communis) oil seeds:[6][13]}

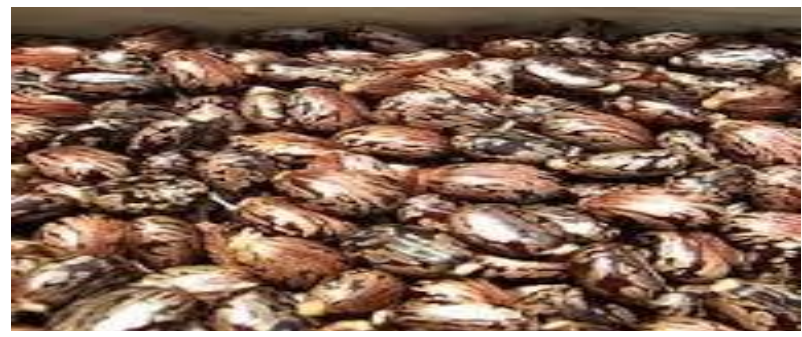

Free fatty acid composition in percentage

Linolenic: 0.33

Linoleic: 0.61

Oleic: 2.28

Stearic: 0.52

Palmitic: 0.46

Recinoleic: 83.97

Dihydroxylstearic: 0.24

Physico chemical properties of castor seed oil:
Kinematic viscosity mm2/s (400 C): 109.53

Flash point (0C): 298

Cloud point (0C): 15.8

Fire point (0C): 335

Density $(\mathrm{Kg} / \mathrm{m} 3): 962.8$

Iodine value: $82-88$

Saponification Value: 175 - 187

Acid Value (mg KOH): $0.4-4$

Physico chemical properties of castor Biodiesel:

Calorific value $(\mathrm{MJ} / \mathrm{Kg}): 39.5$

Kinematic viscosity mm2/s (400 C): 9.5-10

Flash point (0C): 260

Pour point (0C): -32

Density $(\mathrm{Kg} / \mathrm{m} 3): 0.9$

Cetane number: 45-65

Iodine value: 80

5)Neem (Azardica Indica) oil seeds:[4][16]

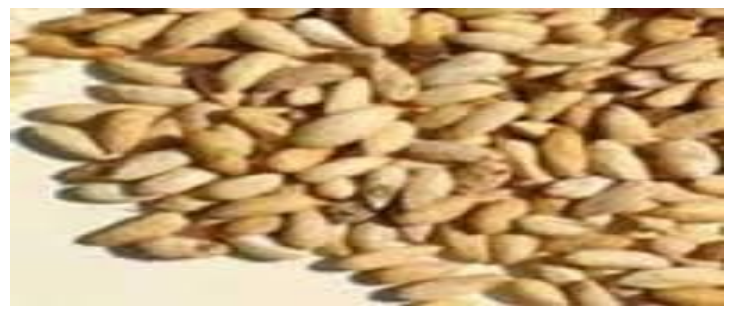

Free fatty acid composition in percentage

Linoleic: 6-16

Oleic: $25-54$

Stearic: $9-24$

Palmitic: $16-33$

Linolenic: $7-12$

Palmitoleic: 4-8

Physico chemical properties of neem seed oil:

Calorific value (MJ/Kg): 29.97

Kinematic viscosity mm2/s (400 C): 37.42

Flash point (0C): 150

Pour point (0C): 7

Cetane number: 31

Refractive index: 1.47

Iodine value: 80

Density $(\mathrm{Kg} / \mathrm{m} 3): 1024$

Physico chemical properties of neem Biodiesel:

Calorific value $(\mathrm{MJ} / \mathrm{Kg}): 39.4$

Kinematic viscosity $\mathrm{mm}^{2} / \mathrm{s}\left(40^{\circ} \mathrm{C}\right): 4.16$

Flash point $\left({ }^{\circ} \mathrm{C}\right): 175$

Cloud point $\left({ }^{0} \mathrm{C}\right): 13$

Pour point $\left({ }^{\circ} \mathrm{C}\right): 10$

Density $\left(\mathrm{Kg} / \mathrm{m}^{3}\right): 884.26$

Cetane number: 46

Saponification Value: 117

Acid Value (mg KOH):0.26

Calorific value $(\mathrm{MJ} / \mathrm{Kg}): 35.68$ 


\section{International Journal of Science and Research (IJSR) \\ ISSN (Online): 2319-7064}

Index Copernicus Value (2013): 6.14 | Impact Factor (2014): 5.611

\section{Conclusion}

Edible oils are in use in developed nations such as USA and European nations but in developing countries the production of edible oils are not sufficient. In a country like India, there are many plant species whose seeds remain unutilized and underutilized have been tried for biodiesel production. Non-edible oil seeds are the potential feedstock for production of biodiesel in India. These species have shown promises and fulfills various biodiesel standards. India, with its huge waste/non -fertile lands, has taken a well noted lead in the area and commercial production. Proper processing of non-edible oil seeds and transesterification can ascertain the quality of biodiesel and can fulfill the large commercial application.

\section{References}

[1] Brajesh Kumar Mishra \& Dr. Rajat Kumar, 'The Production of Biodegradable Fuel From Nonedible Oilseed In India', Journal of Applied Chemistry 22785736 pp.43-46 (May-Jun 2012)

[2] Hariram. V \& Vagesh Shangar R, 'Characterization and Optimization of Biodiesel Production from Crude Mahua Oil by Two Stage Transesterification', American Journal of Engineering Research. 23200847, pp 233-239

[3] Saroj K. Padhi and R. K. Singh, 'Non-edible as the potential source for the production of biodiesel in India', Journal of Chemical and Pharmaceutical Research, 0975-7384 pp 39-49 (2011)

[4] K. V. Radha and G. Manikandan, 'Novel Production of Biofuels from Neem Oil', World Renewable Energy Congress pp 471-475 (May 2011)

[5] AnyaUzo Anya, Nwobia Noelle Chioma and Ofoegbu Obinna, 'Optimaised Reduction of Free Fatty Acid Content on Neem Seed Oil, For Biodiesel Production', Journal of Basic and Applied Chemistry. 2090-424X pp 21-28 (2012)

[6] J. G. Nangbes, J. B. Nvau, W. M. Buba and A. N. Zukdimma, 'Extraction and Characterization of Castor (RicinusCommunis) Seed Oil'. The International Journal of Engineering and Science 2319-1813, pp 105-109 (2013)

[7] Bobade S. N. and Khyade V. B. 'Preparation of Methyl Ester (Biodiesel) from Karanja (Pogamia Pinnata) Oil'. Research Journal of Chemical Sciences 2331-606X, pp 43-50 (Aug. 2012)

[8] Vivek and A. K. Gupta, 'Biodiesel production from Karanja oil', Journal of Scientific \& Industrial Research, Vol 63, pp 39-47 (2004)

[9] Jolius Gimbun, Shahid Ali, Chitra Charan Kanwal, Liyana Amer Shah, Nurul Hidayah Muhamad Ghazali, Chin Kui Cheng and Said Nurdin, 'Biodiesel Production from Rubber Seed Oil Using A Limestone Based Catalyst', Advances in Materials Physics and Chemistry pp 138-141(2012)

[10] S. G. Bojan and S. K. Durairaj, 'Producing Biodiesel from High Free Fatty Acid Jatropha Curcus Oil by A Two Step Method - An Indian case study', Journal of Sustainable Energy \& Environment pp 63-66 (2012)
[11] Athumani Omari, Quintino A. Mgani and Egid B. Mubofu, 'Fatty Acid Profile and Physico Chemical Parameters of Castor Oils in Tanzania', Green and Sustainable Chemistry, pp 154-163 (2015)

[12] R. Sattanathan, 'Production of Biodiesel from Castor Oil with its Performance and Emission Test' International Journal of Science and Research 23197064 (2013)

[13] Adebayo Tajudeen Bale, Rofiat Tosin Adebayo, Damilola Tope Ogundele, Victoria Tosin Bodunde, 'Fatty Acid Composition and Physicochemical Properties of Castor Seed Obtained from Malete, Moro Local Government Area, Kwara State, Nigeria', Chemistry and Materials Research, 2225-0956 (2013)

[14] Jumat Salimon, Dina Azleema Mohd Noor, A. T. Nazrizawati, M. Y. Mohd Firdaus and A. Noraishah, 'Fatty Acid Composition and Physicochemical Properties of Malaysian Castor Seed Oil', Sains Malaysian, pp761-764 (2010)

[15] Penugonda Suresh Babu and Venkata Ramesh Mamilla, 'Significance of Biodiesel use as I. C. Engine Fuels', International Journal of Advanced Engineering Research and Studies, 2249-8974 pp 4043

[16] Aransiola EF, Betiku E, Ikhuomoregbe DIO and Ojumu TV, 'Production of Biodiesel from crude neem oil feedstock and its emissions from internal combustion engines', African Journal of Biotechnology 1684-5315, pp 6178-6186 (2012)

[17]K. Anbumani and Ajit pal Singh, 'Performance of Mustard and Neem Oil Blends with Diesel Fuel in C. I. Engine', ARPN Journal of Engineering and Applied Sciences 1819-6608(Apr.201) 